\title{
Africa
}

http://journals.cambridge.org/AFR

Additional services for Africa:

Email alerts: $\underline{\text { Click here }}$

Subscriptions: $\underline{\text { Click here }}$

Commercial reprints: $\underline{\text { Click here }}$

Terms of use : $\underline{\text { Click here }}$

\section{Specialist Knowledge Practices of Craftsmen and Clerics in Senegal}

Roy Dilley

Africa / Volume 79 / Special Issue 01 / February 2009, pp 53 - 70

DOI: 10.3366/E0001972008000600, Published online: 03 March 2011

Link to this article: http://journals.cambridge.org/abstract S0001972000087945

How to cite this article:

Roy Dilley (2009). Specialist Knowledge Practices of Craftsmen and Clerics in Senegal. Africa, 79, pp 53-70 doi:10.3366/ E0001972008000600

Request Permissions : $\underline{\text { Click here }}$ 


\title{
SPECIALIST KNOWLEDGE PRACTICES OF CRAFTSMEN AND CLERICS IN SENEGAL
}

\author{
Roy Dilley
}

The key vernacular concept in Pulaar that forms the focus of this article is gandal. Gandal can be translated as 'knowledge' or 'science', and it is linked to the verb andude, meaning 'to know' or 'to have a knowledge of' a particular subject. The related term gandudo (plural, andube) can be glossed as 'savant', whether in the form of a 'magician' or a literate Muslim scribe (Gaden 1914: 4). Gandal refers to all forms of specialist knowledge that are required in order to carry out particular tasks, and it embraces both Sufi Qur'anic or religious learning (gandal diine) or 'white' lore and knowledge (gandal danewal), as well as craft and occupational lore which is classed as 'black' (gandal balewal), the expertise of the so-called 'castes'. ${ }^{1}$ The term gandal invokes both the sense of lore/knowledge and a general mystical power that can be used to bring about effects in the world. I have also translated it here and elsewhere (Dilley 2000 and 2004) as 'knowledge-power', for it is both a body of learning and a form of agency that results in effects being brought about by means of that learning. ${ }^{2}$ The word 'lore' in English retains some of the sense suggested by the Pulaar word gandal, namely its connection to specialist, exclusive knowledge, with religious and spiritual connotations. However, it misses one of the essential aspects for Pulaar speakers: that is, it can be used synonymously for the idea of power, to bring about effects in the world. To have gandal suggests that a person is capable as well as knowledgeable; he or she can use knowledge to bring about effects, for knowledge is linked to power. Knowledge and power are ultimately linked in the figure of Allah, one of whose ninety-nine names is Ganndo, 'The-All-Knowing'. Knowledge can bring about effects, and one of those effects is to bring further knowledge by means of the power it entrains, especially through dreams or encounters with spirits (see Dilley 1992).

Gandal is linked to a range of activities, from the practical manifestation of particular specialized skills and talents to a set of practices that are considered to draw on often invisible, non-human,

Roy Dilley is Professor of Social Anthropology at St Andrews. He specializes in the study of Haalpulaaren (Tukulor) social organization and culture in Senegal, and published Islamic and Caste Knowledge Practices among Haalpulaaren, Senegal: between mosque and termite mound with the IAI. Other research interests include anthropological theory and cultural economics, and he is editor of two thematic collections entitled Contesting Markets: analyses of ideology, discourse and practice and The Problem of Context.

${ }^{1}$ Haalpulaar society is characterized by the existence of social ranks: the freeborn; the menand-women-of-skill (nyeenybe); and, in the past, bondsmen and women. Each social rank is comprised of specific social categories or 'castes', such as weavers and blacksmiths among the men-of-skill, and clerics and fishermen among the freeborn.

${ }^{2}$ See Schmitz (1985), who translates the term as 'savoir-pouvoir', which could be contrasted with 'savoir-faire', 'know-how' or practical knowledge. 
spiritual agents. These might be glossed as 'magic' or, better, 'powerpractices'. Part of my intention here is to analyse the foundations of these purportedly 'magical' acts in terms of knowledge-power (gandal), or lore, by means of an archaeology of specialist thought and practice.

A person possessing gandal can bring about effects in the world, not necessarily through physical strength (sembe) or force or energy (doole), nor necessarily through the power and authority of political office (laamu). Instead effects are brought about through the potency inherent in lore or gandal itself acting through the person. Someone who is capable of performing a range of tasks is called a baawo, a term linked to the verb waawde, 'to be able'. Baawo, also the title of the ritual initiator of boys, refers to a person who possesses knowledge (gandal) of, and powers linked to, spiritual matters. In the figure of the baawo, the able-man, is represented the combination of knowledge and the ability to act, that is, a form of human agency stemming from the possession of lore. Another of the ninety-nine names of Allah is Bawdo, 'The-Able-One'.

I have, therefore, coined the translation 'knowledge-power' rather than 'lore' for the Pulaar word gandal in those contexts specifically where it is this aspect of mystical causation that is to be highlighted. Elsewhere I have resorted to the simple gloss 'lore'.

The origin of gandal is ultimately the spiritual world. Since there are different sorts of spirit being, different sorts of knowledge can be derived from them, such as 'black' lore in relation to the spirits that animate craft occupations, and 'white' lore from those beings associated with the 'higher' arts of Islamic learning and knowledge. The world of spirits is the fons et origo of many of the men-of-skill crafts, their knowledge and their expertise; and superior ability in the craft is discussed in terms of one person possessing more or greater gandal than another. The concept of gandal does, however, open up for inspection the relationship between human knowledge gained via experience in the world and revealed knowledge generated by means of specialist techniques. I will return to this topic below.

Gandal is likened to a vast field (ngesa gandal ine yaaje, literally 'the field of gandal is vast'), which is divided into specific plots or areas of expertise. The possession of lore in itself does not yield benefits or produce effects, but has to be linked to human effort in mobilizing that knowledge for particular effects. ${ }^{3}$ The metaphor of the field for gandal is particularly apt, for land in Fuuta Toro is rigidly divided for cultivation on the basis of membership of social categories. The plots of cultivable land in the flood basins are allocated according to social criteria: the lower the plot of land in a flood basin, the higher the social rank of the title holder. Likewise, the field of lore is also divided according to social specialization.

\footnotetext{
${ }^{3}$ This idea is illustrated by the maxim: 'Gandal is a field, but if it is neither worked on nor looked after, it will yield no harvest' (Gandal ko ngesa, soko noon, so remaaka reenaa, sonyetaake) (Gaden 1931).
} 
Specialized forms of practice are linked to specific areas or bodies of knowledge-power; but only some kinds of action and certain types of human agency are marked out in this way. Gandal is the domain of the specialist. It requires effort to acquire lore and knowledge, and perseverance and dedication to maintain its efficacy. Some domains within the field of gandal are exclusive to particular social categories whilst others are open for all to learn; some are by their nature in the public realm whilst others are private, esoteric and secret, and access to them is through initiatory procedures. Many important arts are open for anyone to learn, if the person is able to be apprenticed to an expert willing to teach them. However, because of the initiatory procedures involved in apprenticeship, these arts are in practice limited to members of specific social categories.

A number of occupations and arts are open to all, such as witchhunting, curing or divination, and yet there is a sense that they are by association close to the expertise of the men-of-skill. Members of other social categories tend to avoid these associations. There is an elective affinity between divination and witch-hunting on the one hand, and craft occupations on the other, and this connection is made via the medium of spirit forces of the wild that men-of-skill are thought to be close to, making them particularly good witch-hunters, diviners, and so on. ${ }^{4}$ All of these arts are not only classed as 'black lore', gandal balewal, but are also referred to as gandal aada, lore of local customs and traditions, from the Islamic conception of adat (local customary practice).

The opposition between white lore and knowledge and black lore and knowledge connotes the separation between locally conceived Islamic specialists, the toorobe clerics in particular, and craftsmen or men-of-skill, along with other specialists whose occupations or arts are considered to be 'non-' or 'pre-Islamic' by certain sectors of the local Muslim community. These latter specializations are thought to lie outside exclusive Muslim expertise, and each of them has its own specific body of lore and knowledge classified under the rubric 'black'. That is, they represent competing realms of power and knowledge that stand in opposition to that of the toorobe clerics. ${ }^{5}$

I now turn to the processes of the transmission of these different bodies of lore, which are considered to be ideologically distinct. Indeed, many commentators regard 'black' lore and knowledge to be of preIslamic origin, and 'white' lore and knowledge to be of Muslim

\footnotetext{
${ }^{4}$ Kante, discussing blacksmiths in Mali, suggests a similar affinity in that the connection between smithing and healing or magic is through the friendships craftsmen forge with spirits. These powers assist them to become diviners, seers, healers, and indeed feared 'magicians' (Kante 1993: 29).

${ }^{5}$ The craft occupations I focus on here are the domain of men alone, for women are excluded from weaving, blacksmithing and so on. I also focus on the Islamic education of males, for these are the vast majority of pupils in Qur'anic schools. Gemmeke's article in this volume throws light on the under-studied topic of women gaining access to Islamic knowledge and to status in the Muslim community.
} 
provenance. I aim to reflect upon a series of knowledge practices among Sufi Islamic clerics on the one hand, and craftsmen and later witchhunters on the other, with a view to highlighting a range of continuities in local conceptions of knowledge in different social domains. Thus, while the domains of black and white appear to be ideologically distinct, with different putative origins attributed to them by local commentators, I argue that there are numerous areas of commonality.

\section{APPRENTICESHIPS AMONG WEAVERS}

Weavers comprise one of the categories of artisan making up the menof-skill social rank. I use them as an example here to illustrate the processes of learning a 'black' body of lore.

A weaving apprentice is, in the early stages of his career, expected to copy the work of his master. During this period, knowledge is not articulated or verbalized, but is transmitted through mimesis. Very soon after starting an apprenticeship, a boy will be asked to weave at a loom set up for him by his master, and the production of saleable cloth will begin from this early stage. He will also be asked to carry out repetitive tasks such as bobbin-winding and so on, for his master or other weavers in the group. The yarn, the loom and all the necessary materials for production are provided for the boy, and the master retains any profit gained by the sale of the boy's cloth.

The order in which tasks are learned does not match the order of production (Lave and Wenger 1991: 95-6); indeed, something like the reverse takes place: the apprentice produces finished cloth early on in his career, but will only learn other central tasks about the design of cloth and the setting up of the loom much later. Apprentices are looked upon, therefore, as relatively sound investments since they are economically viable from quite soon after the start of their training.

The acquisition and mastery of most techniques involved in cloth production resides to a large extent not in the figure of the master weaver but instead in the organization of a weaving group which the master organizes - that is, within a 'decentred' 'community of practice' (Lave and Wenger 1991). At later stages in the training, the focus narrows to the dyadic relation between master and learner, a relationship along which a form of 'disembodied' and verbalized knowledge is passed. This is especially the case in the laying out of the warp threads in various colourways and the eventual threading up of the loom. In this regard, the master-apprentice relation becomes paramount.

The more intricate tasks of weaving that follow the development of skills as a cloth producer may be taught many months if not years later. The preparation of threads to compose a warp requires much consideration. Large quantities of thread are necessary-involving a considerable capital outlay - to make up a warp ball. To lay threads in the correct number, in the correct order, and in combination to achieve a desired pattern is a demanding task, which usually requires 
constant supervision from the master weaver. Tying a new warp into a loom is a task that demands patience, dexterity and a sound grasp of the principles of yarn interlacing. Whether fully trained or not, weavers will often lend each other assistance in these, the most demanding tasks of all.

These procedures are analytically and practically the most difficult to grasp. A weaver has to develop a deftness of touch and a calm and patient manner to carry them out. He also needs to acquire an ability to deconstruct a cloth into its component interlacings and thread combinations; that is, to imagine what the elements of yarn as warp and weft will produce once they are brought together as finished cloth on the loom. This procedure also necessitates the ability to calculate exactly how much thread it will take to make up a warp ball prior to starting work on a commission. Thread for the weft can be bought piecemeal as the work progresses; that for the warp must be assembled in total.

A master will actively intervene in the teaching of these aspects of cloth production. He shouts instructions, exclamations and curses at the youth, often seen fumbling his way through a tangle of threads and becoming increasingly tied up in knots. This is one of the stages demanding the most explicit form of teaching and instruction within the whole body of craft practice. A master has too much at stake in terms of capital investment in yarn to allow too much experiential learning at this stage. Moreover, if he wishes to curtail an apprentice's training so that he will remain dependent upon him, the master will offer few opportunities for the youth to practise these tasks, and will not be forthcoming over the finer points of cloth design or its translation onto a loom.

Two stages of learning in a weaving apprenticeship have thus far been described: (1) imitative repetition of cloth production; (2) guided tuition during the preparatory stages of loom assembly. Each of these stages emphasizes one form of learning over another: the first revolves primarily around repetitive practice and mimesis absorbed through continued participation; the second brings more to the fore verbal instruction and the conscious 'implanting of knowledge' into a pupil. To attempt to separate too rigidly these two aspects or to classify one activity solely in terms of mimetic practice and another as 'cerebral' learning would be to falsify the experience and process of learning. These are perhaps best conceived as aspects of a set of social relations and interactions, in which either one or the other mode of learning is emphasized, although not exclusively; each one can nonetheless be distinguished clearly at an analytical level.

The final stage of learning the craft, appropriate only to mature weavers, involves the acquisition of gandal mabube or 'weaving lore' or 'knowledge-power' (see Dilley 1989 on its transmission during and after apprenticeship). Weaving lore comprises myths of origin about the craft, a corpus of magical verses, and incantations for protective or offensive purposes against other weavers or other people in general. Instruction in these matters is given in a highly didactic context, not dissimilar to that between a Qur'anic master and his disciple. 
A master weaver, or jarno, is a title specific to weaving alone; an apprentice is referred to as a jangina, literally a 'learner' in a general sense. The word for 'learner' is related to the words jangirde or 'school', and jangude, meaning 'to read', 'to learn to read', or 'to follow teachings from a master'. There are obvious parallels drawn here by Pulaar speakers between the process of learning and teaching at Qur'anic school, on the one hand, and what takes place in a weaving compound, on the other. I will return to these parallels later.

Many aspects of their lore-such as origin myths and legends-are transmitted in a relatively accessible and open way. Powerful verses, incantations and spells, by contrast, are considered to be especially esoteric and are passed on only during moments of intimate interaction between master and learner. It is paramount that other people do not overhear such knowledge, for it is considered to be dangerous to others as well as something personal to the master himself. This is knowledge that he has won through a life-long struggle with himself, with others and with the spirits from whom the magical words, incantations and knowledge are derived. It is passed on in a conspiratorial whisper in a secluded corner of a compound or in a room from which other family members have been evicted. This aspect of learning is a very 'centred' process, focusing exclusively on the dyadic relation between teacher and learner, to the exclusion of all others. This mode of didactic instruction is unlike any other form of learning employed during the course of a weaving apprenticeship, although that does not mean to say that mimesis is not part of the process.

Knowledge is acquired in the latter stages of a weaving apprenticeship not simply by individual instruction, but also by means of dreaming and other forms of spirit contact. Indeed, for a master weaver, musical and linguistic creativity in poetry, song and in the 'composition' of verses and incantations, as well as ideas for new cloth designs or thread interlacings, all come from the spirit world. A person will awake with, or find implanted in his mind during the day, a new idea or inspiration. This is taken by the dreamer or innovator to be the result of spirit agents who have visited upon the person a new aspect of knowledge about his craft (Dilley 1992). Through dreams and other forms of spirit intervention, the weaver is linked through no obvious agency or activity to sources of knowledge, power and learning. The weaver becomes the vehicle through which knowledge creation works. His responsibility is to maintain himself in a receptive state to receive this sort of learning.

In summary then, the stages of learning during a weaving apprenticeship are as follows. First, the young apprentice participates in the physical world of routine and repetition through practical mimesis. This participation gives way to, or is complemented by, forms of verbal instruction and occasional didactic methods as learning progresses. The third and final stage, the learning of gandal, involves individual instruction by the master to his apprentice. This can then develop into a form of individual quest for knowledge-power through dreams and spirit contact-something akin to participation as a kind of 'orientation 
towards reality' (Tambiah 1990). These stages mirror to some extent those outlined by Marchand in his analysis of Malian masons: from technical, embodied and experiential knowledge, through propositional knowledge, and finally to secret knowledge.

\section{LEARNING THE QUR'AN AND SUFI ISLAMIC ARTS}

Muslim religious practitioners or 'marabouts' are referred to in Pulaar as seernaabe (ceerno, singular), a title that is derived from the verb seernude, meaning 'to make separate' [that is, the truth from falsehood]. ${ }^{6}$ A ceerno, then, is someone who can distinguish truth from falsehood, one who has mastered a body of Islamic learning, and is equivalent to the Arabic 'alim, a scholar in the religious sciences. ${ }^{7} \mathrm{He}$ can also achieve the status of a master marabout (sirruyankoobe, or singular, sirruyanke), one who has a specialized knowledge of Islamic secrets or mysteries (sirru), or finally the status of saint or 'friend of Allah' (waliyaabe or, singluar, waliyu). Saints have attained a measure of divine grace and have achieved direct communion with Allah, a state that is referred to as wusuli, a union or rebirth in Allah in the Sufi tradition.

Access to these statuses within local Islam is achieved through a series of stages of learning in Qur'anic studies and initiatory apprenticeship in Islamic arts and sciences often centred around a Sufi brotherhood, the most popular of which is the Tijaniyya among Haalpulaars. Virtually all children from the age of seven years onwards will attend a local Qur'anic school $(d u d a l)^{8}$ located in their village or urban neighbourhood in order to attain a basic knowledge of the Muslim religion. The early stages of Qur'anic study are dominated by rote learning, the memorization of texts without translation or comment. Emphasis is placed on precise and correct recitation of first the Arabic alphabet and then simple texts, although little attempt is made on the part of instructors (janginoobe) to convey the meaning of the words. Children in local schools sit on the floor chanting in unison the prescribed texts, swaying gently to the rhythm of the words as they recite them in a mesmeric fashion. Longer and more complex texts and Qur'anic verses are progressively introduced, until such time as a pupil has command over a wide range of scripts that can be performed orally from memory. This stage of learning, I would suggest, corresponds to the mimetic practices of a weaving apprenticeship.

\footnotetext{
${ }^{6}$ The word 'marabout' was the French pronunciation of the Portuguese word marbuto, a deformation of the Arabic morâbit or 'soldier-monk', and is today common in local parlance in Senegal and elsewhere in West Africa.

${ }^{7}$ See Gemmeke's article in which she addresses the question of women marabouts in Senegal. See also Coulon 1988.

${ }^{8}$ The word dudal strictly refers to the nocturnal fire or hearth around which Qur'anic pupils (almube) sit and recite verses at night, but is employed figuratively for the school itself. The renown of a school is measured by the height of ashes in the hearth, under which protective talismans are buried.
} 
Few pupils will continue as far as the higher stages of learning, and most of those who do are males. It is only then that an understanding of the Arabic language and a sense of the meaning of the texts begin to develop through the now more formalized study of language and linguistics. By the time a youth reaches his early to mid-twenties, he might expect to have finished the first part of his training, sufficient for him to set up as a primary Qur'anic teacher in his own right.

The second stage of learning involves Qur'anic exegesis (tafsir koran), is focused on advanced study of religious works (the Hadith and the biography of the Prophet (sira)), and is often referred to as gandal koran or Qur'anic knowledge. These arts are mastered only by a selected group of students. The passive rote learning of earlier stages is replaced by the detailed interpretation of texts, which the student will have to grasp and then repeat back to his teacher until it is fully understood. ${ }^{9}$ At the successful completion of these studies the student graduates with the title of tafsir, an honorific acquired when the student has learnt to recite by heart large parts, if not all, of the Qur'an. He must be able to give historical interpretation and religious exegesis of the holy book, chapter by chapter, verse by verse. Supplementary to this form of learning are yet further steps in the development of Qur'anic study, in particular the interpretation of hidden or esoteric meanings of the Qur'an (ta'wal) (Brenner 2000a).

The study of the Qur'an at introductory and advanced levels is open to most students who desire knowledge or have the ability to pursue more complex higher disciplines. The realm of secrets and mysteries, by contrast, is only accessible to those who can find a suitable master willing to accept a pupil as a taalibe, a disciple, under an initiatory form of transmission (talqin) of Qur'anic knowledge and mystical sciences. This relationship can be initiated through joining a brotherhood, such as the Tijaniyya, whereby a petitioner seeks instruction from a muqaddam to be able to recite the litany or wird of the sect. This instructor may then become the disciple's murshid or his spiritual guide. The Tijani litany comprises the laziima, considered to be part of one's private devotions, and the wazifa that contains formulary prayers chanted in collective devotions at the mosque (see Dilley, in press). The recitation of these texts alone can have a transformative effect on the worshipper through the power of the word of the litany, whose literal meaning may remain obscure. This is a form of learning set within a dyadic relationship of guide and disciple.

Secret Islamic knowledge (gandal sirru), knowledge of mysteries, involves, as Brenner puts it, 'a level of understanding beyond that communicated by the intellect and is reserved for the very few who have achieved direct knowledge of the Divine through gnosis' (2000a: 341). Qur'anic apprenticeship is thus transformed into an initiatory process, in which the disciple forms a very particular relationship with

\footnotetext{
${ }^{9}$ See Ba (1985-6) on the specialist centres of learning dotted throughout Fuuta Toro which advanced students may attend.
} 
his master. Not only does he seek to absorb the substance of the master's teaching, but he is also drawn into a personal relationship with him as a spiritual guide (murshid). Spiritual chains of transmission of knowledge, silsila, are set up between disciple (murid) and master, and these chains may connect back to the founding Shaykhs of a Sufi order. The links in these chains are not necessarily those of blood or lineage, but can be of 'breath' or 'saliva' (tuute), the media through which blessings and baraka or spiritual grace are passed from master to disciple (Schmitz 2000).

Gandal sirru or 'knowledge of secrets' has a number of applications in a range of arts practised, as well as offered as services, by marabouts. This knowledge takes the form of a range of practices often referred to as dabare or 'esoteric science', which might equally be considered as techniques to tap into a variety of sources of spiritual power; they are another sort of power-practice known in the French literature as 'maraboutage'. Maraboutic arts involve the capacity of human beings to attempt to contact and manipulate dangerous, hidden, spiritual forces. These practices are not uncontested, for they attract criticism in particular from non-Sufi Muslims who denounce them as shirk (ascribing partners to God) or sihr (illegitimate magic).

Personal communication with Allah is the highest form of knowledge that can be acquired, and this is part of a spiritual quest (tarbiyu or tarbiyya) to achieve a union with or rebirth through Allah. ${ }^{10}$ This mystical aim lies at the heart of Sufism (tasawwuf). One technique to achieve communication is to conduct periods of retreat, khalwa, often for up to seven days or more, during which time the marabout will pray and recite Qur'anic verses in a bid to open the doors of human perception to divine inspiration. ${ }^{11}$ This may come in the form of visions, dreams and prophetic revelation, and may be engendered by a range of spiritual forces from Muslim jinn to angels. This technique can be used to acquire knowledge either for the marabout himself or for clients who might seek advice, healing and so forth from him. ${ }^{12}$ While the gifts of visions and prophecy associated with sainthood are by and large accepted as the respectable face of esoteric Muslim sciences, those involving the manipulation of the existing state of affairs and of the

\footnotetext{
${ }^{10}$ Evans-Pritchard (1949: 2) formulated the following description:

The aim of Sufism has been to transcend the senses and to attain ... identification with God so complete that there is no longer a duality of 'God' and 'I', but there is only 'God'. This is brought about by asceticism, living apart from the world, contemplation, charity, and the performance of supernumerary religious exercises producing a state of ecstasy in which the soul, no longer conscious of its individuality, of its bodily prison, or of the external world, is for a while united with God.

11 'Khalwa is a form of knowledge particular to grand marabouts, a particular possession of saintly persons' (Gaden 1931: 258). See also Triaud (1988) on the practice of khalwa in West Africa.

${ }^{12}$ Before decisions of crucial importance are taken, a khalwa retreat may be organized. One famous case reported in the literature is that of El Hajj Umar Taal who, prior to setting off on his jihads of the mid-nineteenth century, conducted khalwa (Robinson 1985).
} 
predictive sciences are less respectable and more ambiguous (Brenner 1985).

The most contentious areas of what French-speakers label 'maraboutage' include those sciences involving the manipulation of the power of letters, words and numbers, in particular the knowledge and use of the names of Allah, numerology and the tracing of magic squares and talismans (haatumeere). Maraboutic practices, known as lasrari, extend the language-based discipline of Qur'anic study from the mundane arts of exegesis and interpretation to a practical science that taps into spiritual forces and powers inherent in, or evoked by, writing, script and text. Binndi is the general category of written Qur'anic verses used in talismans (haatumeere) and amulets (talki), and aaya are therapeutic Qur'anic verses used as 'script-potions' or 'erasures' to treat the body of a client or to be ingested. Binndi and aaya are to the marabout what incantations (cefi) and herbal potions are to weavers and other craftsmen, and to witch-hunters and magicians (wileebe, or bileejo).

The dynamics of power and hierarchy between Islamic learning and craft knowledge can be illustrated by the case of a master weaver and diviner who was advised by his marabout to give up cowrie divination in order to be accepted more fully into his local Tijani devotional group (daaira). ${ }^{13}$ With a fine reputation as a craftsman, poet and singer, and healer, he gave up some of his 'black arts' to become a regular imam-essalat, leader of prayers, within the group. Pressure from the marabout, who represented a more socially dominant form of knowledge, was sufficient for the weaver to reassess his priorities in relation to the more marginal knowledge practices he had until then pursued.

\section{REFLECTIONS ON TWO SYSTEMS OF LEARNING}

The two systems of learning considered above relate to different bodies of knowledge that are conceived as being ideologically distinct by local commentators. Nonetheless, what has been illustrated so far suggests that there is a series of commonalities regarding the modes of learning of both a weaver and a taalibe, a Muslim disciple under the tuition of a marabout.

First, craft apprenticeship and Islamic training constitute disciplinary practices and techniques of power. One aspect of these practices is the categorical separation of master from learner, from which arises relations of power and control. It is a disciplinary practice that is aimed at reproducing generations of skilled practitioners who compete not only in terms of securing an economic livelihood but also in relation to a body of knowledge-power that is the foundation of the two respective areas of expertise. Within the conditions of possibility of these disciplinary practices, knowledge as power brings about effects

\footnotetext{
${ }^{13}$ For more details on daairas and their functions see Dilley (in press).
} 
in the world, and power relationships provide the means for the creation and transmission of knowledge. Forms of learning are ways of controlling access to this knowledge and the power it brings. Control rests on there being imagined a body of knowledge to possess, as well as a set of techniques to acquire it. Controlled access to the possession of items within a corpus of lore in turn is the means to further the acquisition of knowledge through the power it brings. The power of this disciplinary practice is not just to restrain and constrain those who operate within it; it also enables, empowers, creates and generates forms of practice and types of knowledge and forms of subjectivity (Foucault 1979 and 1984; Arens and Karp 1989). Moreover, it produces an arena of contestation more deadly than that simply between economic rivals in competition when either practising weaving or dispensing Muslim cures. The grounding of the disciplinary practice upon a system of knowledge-power provides the conditions for an agonistic will-to-power that is manifested at an individual as well as a group level. This is seen in a search by individual master weavers to situate themselves within, and to organize the world according to, the powers and potencies they possess; it is seen too in the attempts by social categories or 'castes', such as mabube weavers or the Islamic clerics, to impose a sense of order upon the world through a body of knowledge derived from one type rather than another type of spirit being. And it is through an examination of the various processes of learning aspects of a particular craft that light is shed upon the cultural politics of membership of a 'caste' group, and of knowledge that is derived from practical participation as well as from revelation through the affinities of being.

Second, some of the connections between an apprenticeship in weaving and the processes of Islamic learning can be drawn out. There is a series of continuities between the two. Mimetic practice of rote memorization and recitation of Qur'anic text is characteristic of the early stages of a youth's experience at Qur'anic school, just as mimetic practice for the weaving apprentice defines the start of his training. These mimetic practices have the consequence of disciplining bodies and constituting particular forms of subjectivity. ${ }^{14}$

Higher stages of learning are marked by explicit didactic methods aimed at highlighting specific skills: in the case of Islamic training, the deciphering of meaning and the interpretation of texts, until now constituting only a series of sounds to be recited mellifluously in Arabic; for weavers, the stages of learning thread interlacing and the set-up of the loom. Furthermore, the language of Arabic itself becomes the focus of teaching, as well as the medium through which education is developed. Thus, there is a verbalized and cerebral stage to Islamic learning that parallels the second stage of a weaving apprenticeship.

\footnotetext{
${ }^{14}$ Parallels can be drawn here with what Graw discusses in his article in this special issue on Senegambian divinatory practices. He emphasizes a distinction between a mastery of the preliminary, technical aspects of divination and the later development of 'intuitional' knowledge by diviners. The 'force' and 'intuition' of a diviner's practice might be seen to find a counterpart in the later stages of learning I describe here.
} 
Finally, the acquisition of esoteric weaving gandal is mirrored in the mystical practices of Muslim marabouts whose knowledge (gandal diine or religious lore) is transmitted in the context of an intense dyadic relationship in which the disciple identifies strongly with his master. Furthermore, while dreaming becomes an important medium for the acquisition of knowledge for a master weaver (see Dilley 1992), there exists a parallel range of disciplinary practices for the marabout. These are aimed at opening the doors of human perception of the cleric to forms of esoteric Islamic knowledge inspired by divine beings. Religious retreats, meditative practices, prayer and dream divination are all included in these disciplinary practices. One central area of expertise for these marabouts is the control of Arabic literacy and the associated forms of 'book magic' (Goody 1968) that constitute one of the most significant forms of power practice they possess.

Brenner (2000b) refers to the 'esoteric episteme' that underpins a variety of forms of West African Sufi mysticism, wherein knowledge of Islamic esoteric sciences and arts is based upon the 'oral transmission of the written word', effected through a highly personalized relationship of disciple (taalibe or murid) and marabout. This idea of an 'esoteric episteme' can be broadened, I would suggest, to include those knowledge practices of weavers, whose body of weaving lore is nonetheless regarded as culturally distinct from that of Islamic experts. In other words, a common epistemology seems to underpin both forms of knowledge practice and their respective conceptions of knowledge as something to be acquired through initiatory learning.

I now turn to a set of comparisons and contrasts that can be drawn between the marabout and the witch-hunter, another expert in 'black' lore and knowledge. In this section it is suggested that how knowledge and skills are transmitted influences the ways in which networks of expertise are developed, and how the role of the expert is understood within wider fields of social authority and legitimacy. ${ }^{15}$

\section{THE KNOWLEDGE AND PRACTICE OF THE WITCH-HUNTER}

Witch-hunters (wileebe, singular bileejo) are the counter-agents to witches (sukunyaabe) whose practice of witchcraft (cukunyaagu) is associated with the eating of human flesh and the drinking of blood; hence, witches are also called 'those who eat others' (nyamneebe) or 'the drinkers of blood' (yaroobe yiiyam). Witches are thought to be in league with spirits or jinn from the bush, who are often summoned from tamarind trees to help them and assist in securing the shadow-self (mbeelu) of the witch's victim, which is held in safe-keeping until the witch demands its return. The witch-hunter is a religious functionary, operating in parallel with Muslim cleric specialists, yet this role is regarded locally as being in tension with that of marabouts. While the

\footnotetext{
${ }^{15}$ See Jansen's article in this volume for an argument emphasizing expertise as a function of social power and network.
} 
bileejo deals with afflictions that attack the victim's 'soul', the marabout is concerned with the protection, care and well-being of the fittandu or 'soul', which is at risk from a range of spiritual forces such as evil jinn, as well as from the effects of interpersonal magic. Jinn act through the medium of wind, and they can be detected by a cool breeze that passes over the skin, which then becomes swollen or inert. The wind, creating a feeling of numbness or a tingling sensation on the body, can also leave limbs or one side of the body paralysed. The mode of action of jinn is upon the exterior of the person, and they will escape with the intellect to cause a loss of mental functions and eventual madness. Witches, by contrast, act upon the interior of the person by entering the body via one of the orifices and eating the victim from the inside.

The bileejo, the counter-agent in dealing with the consequences of witchcraft, does not often choose such a role but is in a sense chosen for it. Being born to a known witch is one way of qualifying to be a witch-hunter; another is by 'election' that is indicated by a set of signs, the most important of which is being born with teeth (jibinaa nyiiye). A child particularly affected by nightmares can be interpreted as coming under the gaze of witches at night, or an 'illness-event' is often the stimulus for a mother, concerned about witchcraft, to take her suffering child to see a bileejo (Tall 1984). This consultation may spur the child to develop this specialization later in life.

The bileejo's art is open to members of all social categories - freeborn and artisan alike. The bileejo with whom I conducted a number of interviews practised his art in a neighbourhood of weavers on the outskirts of a town, and was a member of the mabube weavers social category who had inherited his powers (mbilewaagu) from his mother. $\mathrm{He}$ maintained a spirit shrine, comprising three up-turned pestles buried in the ground, at which he supplicated spirits by pouring libations to them; a practice that was also central to him for acquiring further knowledge of witch-hunting (mbileewu) that was given him by those spirits. This method of acquiring knowledge was in addition to what he had learnt from his mother. He was the only person to keep a spirit shrine in the neighbourhood, a fact that drew scorn from his neighbours, his fellow weavers and even his kinsfolk, who claimed it was shirk and contrary to Muslim law. He was nevertheless continually called upon, especially by women who sought his services for their young children suffering from a range of maladies. The large number of clients he had bore witness to the fact that the treatments he was offering were in demand by the community, which at the same time condemned him for his persistence in what they considered to be nonMuslim or even pre-Islamic practices.

Patients tend to consult a witch-hunter either at night or very early in the morning, for they fear being spotted entering his or her compound. Most people will attempt to visit a bileejo on the sly, at times when few people will be about or when it would be difficult to be detected, for he is a feared and despised member of a community, and most will shun him in public. Although peripheral to the community in many ways, they offer services that many, mostly adolescents or women with young 
children, find important. Clients frequently consult a bileejo when all else has failed, including treatment by a marabout, or when the specific symptoms associated with witchcraft arise. In many ways the bileejo is the inverse of the image of the marabout, who frequently lives at the centre of the village close to the mosque, is associated with public life, and is a positively valued figure in the community. The life of a bileejo is solitary and private, and his or her business is conducted surreptitiously under the cover of darkness. Moreover, there is no community that arises from the network of apprentice relations that exist between witchhunters in quite the same way that marabout-disciple relations create enduring social bonds and long-remembered pedagogic connections. ${ }^{16}$ This contrasts also with the weavers' conception of their own origins and remembered chains of transmission of knowledge by means of recited pedigrees or askos. Furthermore, witch-hunters labour under the knowledge that they will not die in tranquillity but, being caught off guard at one moment or another by an adversary, will eventually be trapped by those who chase them, sent mad and suffer a painful death. They therefore require a range of incantations to protect themselves from their old adversaries and accomplices, who are a constant threat.

\section{THE SOCIAL CONSEQUENCES OF EXPERTISE}

The figures of the bileejo and the marabout are two images that represent mastery of two contrasting domains of power: the bileejo, the master witch-hunter and magician whose arts are considered 'black'; the marabout, the learned cleric whose studies are in 'white' lore of Sufi mysticism. The juxtaposition of these two religious functionaries highlights as well differing social roles that each one plays, and different social consequences of expertise in each case. Expertise is profiled in different ways, for each type carries with it its own sense of legitimacy and a specific arena of authority.

While the bileejo is shunned within the community and consultations take place surreptitiously, often under the cover of darkness, the marabout is a public figure of religious and political importance. There is less fear of public reprimand in consulting a marabout (sirruyanke) versed in Islamic magic and mysteries - despite the fact that some of his practices might be condemned by the pious - than there is in being seen patronizing a bileejo, even if this latter performs a useful social and spiritual function. The role of the marabout is as ambiguous as that of the bileejo (Tall 1984: 157): while the bileejo deals in nefarious forces whose actions may bring benefit and healing to the patient, the marabout is projected as dealing with forces of light whose actions will bring blessing, grace and enlightenment. However, an ambiguity inheres in the marabout's practice, too, for ordinary folk can never be

\footnotetext{
${ }^{16}$ See Tall 1984 on this comparison, and see Schmitz 2000, for example, on 'relations propédeutiques-pédagogiques' among Muslim clerics.
} 
certain exactly what forces he might be dealing in, since the practices associated with secret Islamic lore are by definition hidden from view.

An area of common ground between the art of the bileejo and that of the marabout can be illustrated with reference to the operation and performance of their two forms of power-practice. A bileejo effects his magical powers through the utterance of incantations and the disposal of material charged with the powers of contagion with the target victim: for example, the victim's or the patient's name is inserted in the recitation of an incantation, in order for the utterance to reach its target. In local Muslim practice the person's name is also inscribed at the centre of the design of an Islamic talisman, just as it is interlaced into the recitation of the bileejo's incantations. The name and its intercalation into the structure of the power medium are important to both operations. At the level of practice, therefore, there are lines of comparison to be drawn between the operations and performance of black and white techniques as illustrated by the two types of specialists - the marabout and witch-hunter.

I referred above to Brenner's work on what he defines an 'esoteric paradigm' (2000a) or an 'esoteric episteme' (2000b) of knowledge, which he argues underlies a variety of religious practice throughout West Africa. ${ }^{17} \mathrm{I}$ argued above that underlying knowledge practices in both weaving and Islamic studies was a shared conception of knowledge and epistemology, despite local ideological claims to the contrary. Brenner's esoteric paradigm is founded on 'the idea that a secret and powerful knowledge exists which is available to those who can gain access to it' (Brenner 2000a: 341), although not everyone has the means or capacities to attain the appropriate levels of intellectual or spiritual achievement. The intersections of power relations and access to and control of knowledge constitute an important part of this esoteric episteme, and Brenner has described these features at length with respect to West African Sufi Islam. What I would like to emphasize here are the commonalities among the Sufi formation of knowledge, what I have described for mabube weavers and other men-of-skill, and what has just been illustrated regarding witch-hunters (see also Dilley 1989, 1999, 2000).

Each of the culturally defined domains of knowledge-power (gandal) ultimately shares in a common epistemology based upon the restricted availability of bodies of esoteric lore. The stages of learning I have described above move from imitation of a teacher and repetition of mundane tasks to an informed social practice, which is followed by the possibility of gaining access to hidden knowledge by means of a personal initiatory relationship to a particular master. The acquisition of this knowledge is marked by the donation of a gift from the trainee to the master, often in the form of a head of cattle. ${ }^{18}$ Training takes

\footnotetext{
${ }^{17}$ Brenner's notion of episteme is Foucauldian in conception (see 2000b: 18).

${ }^{18}$ See Dilley (1989 and 2004) for further details on these gifts, Ba (1985-6) on 'graduation' gifts of Islamic scholars in Fuuta Toro, and Wilks (1968: 171) on customary gifts from a student's family to a Qur'anic teacher elsewhere in West Africa.
} 
the form of an initiatory process that progressively reveals hidden domains, wherein proximity to the spiritual entities connected with expert practice entails dangers for the ordinary person. Experts have specialized roles in relation to these secret bodies of lore, whether they be 'caste'-specific practitioners - as in the case of the men-of-skill-or whether they be practitioners who have selected a specialization on grounds other than caste membership.

The figures of the marabout and bileejo in one perspective stand in opposition to each other as experts in two distinct domains of knowledge-power. They also stand in opposition to each other with respect to the social position they occupy and the kind of cultural value and public prominence each attracts. The hierarchical relations of power that inform the articulation of the dominant clerics with marginalized craftsmen groups or those who practise witch-hunting serve to profile 'expertise' in different ways, each one implying its own sense of authority and social range of legitimacy. The expertise of each specialist is a function, I would argue, of a number of inter-related factors: the conception of the knowledge they are thought to possess; the modes of transmission of that knowledge; the nature of sociality and forms of social network that arise from particular knowledge practices. While they might regard themselves to some extent as 'entrepreneurs' or 'ethnic brokers' located in networks created by their own initiative (Jansen, in this volume), I would also want to highlight the centrality of what it is they imagine they possess and how it is that they pass it on.

This analysis attempts to move beyond the idea of 'metaphors of knowledge' and aims to expose local epistemologies, which are deduced from an investigation of 'expert' knowledge practices and indigenous claims to knowledge. It addresses the problem of the creation and transmission of knowledge among specific groups of specialist practitioners in Haalpulaar society, Senegal, following Crick's observation that 'anthropologists speak of the creation of knowledge... without detailing any processes or mechanisms' (Crick 1982: 291). In doing so, I have attempted to understand how different knowledge practices and their associated epistemologies might be contextually integrated at an ethnographic level. These epistemologies work at numerous levels in the gaining of knowledge: through human experience of, and engagement with, the world by means of technical and mimetic practices; through explicit verbal instruction and cerebral learning; and by means of the search for knowledge as a process of revelation.

\section{REFERENCES}

Arens, W. and I. Karp (eds) (1989) Creativity of Power: cosmology and action in African societies. Washington DC and London: Smithsonian Institution Press.

Ba, Omar (1985-6) 'Le rôle des écoles islamiques dans le dévéloppement de la culture arabo-islamique dans le bassin du Fleuve Sénégal'. Doctoral thesis, Université de Paris IV-Sorbonne. 
Brenner, L. (1985) Reflexions sur le savoir islamique en Afrique de l'ouest. Bordeaux: Centre d'Etude d'Afrique Noire, Université de Bordeaux I.

- (2000a) 'Sufism in Africa' in J. Olupona and C. Long (eds), African Spirituality. New York NY: Crossroad.

(2000b) Controlling Knowledge: religion, power and schooling in a West African Muslim society. London and Bloomington IN: C. Hurst and Indiana University Press.

Coulon, C. (1988) 'Women, Islam and baraka' in D. B. Cruise O'Brien and C. Coulon (eds), Charisma and Brotherhood in African Islam. Oxford: Clarendon Press.

Crick, M. (1982) 'Anthropology of knowledge', Annual Review of Anthropology 11: $287-313$.

Dilley, R. M. (1989) 'Secrets and skills: apprenticeship among Tukolor weavers' in M. W. Coy (ed.), Apprenticeship: from theory to method. New York NY: State University of New York Press.

(1992) 'Dreams, inspiration and craftwork among Tukolor weavers' in M. C. Jedrej and R. Shaw (eds), Dreaming, Religion and Society in Africa. Leiden: E. J. Brill.

- (1999) 'Ways of knowing, forms of power: aspects of apprenticeship among Tukulor Mabube weavers', Cultural Dynamics 11 (1): 33-55.

(2000) 'The question of caste in West Africa, with special reference to Tukulor craftsmen', Anthropos 95: 149-65.

(2004) Islamic and Caste Knowledge Practices among Haalpulaaren, Senegal: between mosque and termite mound. Edinburgh: Edinburgh University Press for the International African Institute.

- (in press) 'Daaira, devotional acts and the transformation of space in Senegal, West Africa' in Z. Hirji (ed.), Places of Worship and Devotion in the Muslim World. Oxford: Berghahn Press.

Evans-Pritchard, E. E. (1949) The Sanusi of Cyrenaica. Oxford: Clarendon Press.

Foucault, M. (1979) Discipline and Punish: the birth of the prison. London: Peregrine Books.

(1984) The Foucault Reader, edited by P. Rabinow. Harmondsworth: Penguin.

Gaden, H. (1914) Le Poular, dialecte Peul du Fouta Sénégalais. Paris: Leroux.

- (1931) Proverbes et Maximes Peuls et Toucouleurs. Paris: Institut d'Ethnologie.

Goody, J. (ed.) (1968) Literacy in Traditional Societies. Cambridge: Cambridge University Press.

Kante, N. (1993) Forgerons d'Afrique noire: transmission des savoirs traditionnels en pays malinké. Paris: L'Harmattan.

Lave, J. and E. Wenger (1991) Situated Learning: legitimate peripheral participation. Cambridge: Cambridge University Press.

Robinson, D. (1985) The Holy War of Umar Tal: the Western Sudan in the midnineteenth century. Oxford: Clarendon Press.

Schmitz, J. (1985) 'Autour d'al-Haji Umar Taal. Guerre sainte et Tijaniyya en Afrique de l'ouest', Cahiers d'Etudes Africaines 25 (4): 555-65.

(2000) 'Le souffle de la parenté: mariage et transmission de la baraka chez des clercs musulmans de la vallée du Sénégal', L'Homme 154: 241-78.

Tall, E. K. (1984) 'Guérir à Cubalel: interprétation de la maladie et pratiques thérapeutiques chez les Haalpulaaren dans la vallée du Fleuve Sénégal'. Doctoral thesis, École des Hautes Études en Sciences Sociales (EHESS). 
Tambiah, S. (1990) Magic, Science, Religion and the Scope of Rationality. Cambridge: Cambridge University Press.

Triaud, J-L. (1988) 'Khalwa and the career of sainthood: an interpretative essay' in D. B. Cruise O'Brien and C. Coulon (eds), Charisma and Brotherhood in African Islam. Oxford: Clarendon Press.

Wilks, I. (1968) 'The transmission of Islamic learning in the western Sudan' in J. Goody (ed.), Literacy in Traditional Societies. Cambridge: Cambridge University Press.

\section{ABSTRACT}

This article examines the specialized knowledge practices of two sets of culturally recognized 'experts' in Senegal: Islamic clerics and craftsmen. Their respective bodies of knowledge are often regarded as being in opposition, and in some respects antithetical, to one another. The aim of this article is to examine this claim by means of an investigation of how knowledge is conceived by each party. The analysis attempts to expose local epistemologies, which are deduced from an investigation of 'expert' knowledge practices and indigenous claims to knowledge. The social processes of knowledge acquisition and transmission are also examined with reference to the idea of initiatory learning. It is in these areas that commonalities between the bodies of knowledge and sets of knowledge practices are to be found. Yet, despite parallels between the epistemologies of both bodies of expertise and between their respective modes of knowledge transmission, the social consequences of 'expertise' are different in each case. The hierarchical relations of power that inform the articulation of the dominant clerics with marginalized craftsmen groups serve to profile 'expertise' in different ways, each one implying its own sense of authority and social range of legitimacy.

\section{RÉSUMÉ}

Cet article examine les pratiques de connaissance spécialisées de deux groupes d'" experts " culturellement reconnus au Sénégal: les religieux musulmans et les artisans. Leurs corps de connaissances respectifs sont souvent considérés comme mutuellement opposés, voire antithétiques à certains égards. Cet article a pour but d'examiner cette assertion en étudiant la manière dont cette connaissance est conçue par chacune des parties. L'analyse tente d'exposer des épistémologies locales déduites d'une étude des pratiques de connaissance " experte " et des revendications indigènes à la connaissance. Les processus sociaux de l'acquisition et de la transmission de la connaissance sont également examinés en référence à l'idée d'apprentissage initiatique. C'est dans ces domaines que l'on trouve des éléments communs aux corps de connaissances et aux groupes de pratiques de connaissance. Pourtant, malgré des parallèles entre les épistémologies des deux corps d'expertise et entre les modes respectifs de transmission de la connaissance, les conséquences sociales de cette "expertise" sont différentes dans chacun des cas. Les relations hiérarchiques de pouvoir qui informent l'articulation des religieux dominants avec des groupes d'artisans marginalisés servent à décrire l'" expertise " de différentes manières, chacune impliquant son propre sens de l'autorité et de l'éventail social de légitimité. 